\title{
Evaluation of rapid antigen test in child patients with group A streptococcal tonsillopharyngitis
}

\section{Çocuk hastalarda grup A streptokok tonsillofarenjitinde hızlı antijen testinin değerlendirilmesi}

Fikriye MiLLETLI-SEZGIN¹, Erdal ÜNLÜ²

\begin{abstract}
Objective: The most frequently encountered diseases in childhood are the upper respiratory tract infections. Although in our country the most common agent of tonsillopharyngitis is viral, it ranks high in rates of unnecessary use of antibiotics. Streptococcus pyogenes, which is known as Group A streptococcus, is the most common bacterial agent of acute tonsillopharyngitis. The rate of Group A streptococcus causing cases of tonsillopharyngitis in children varies between $20 \%-40 \%$. The gold standard for diagnosis of Group A streptococcus is the throat culture test. However, faster methods have been developed as it takes 24-48 hours to produce results. This study aims to evaluate the effectiveness of the rapid antigen test by comparing the results obtained from the rapid antigen detection test and throat culture test.

Methods: In this study, the results from 297 throat swab samples that had been sent to our laboratory with a diagnosis of tonsillopharyngitis, which belonged to patients who had presented to the pediatric diseases clinic between the dates of February 2017-January 2018, were retrospectively evaluated. With one of the samples, inoculation to sheep blood agar was performed for the throat culture test, and simultaneously, the rapid antigen test (TOYO, Turklab) was done on the
\end{abstract}

\section{ÖZET}

Amaç: Çocukluk çağında en sık görülen hastalıklar üst solunum yolu enfeksiyonlarıdır. Ülkemizde tonsillofarenjitin en sık etkeni virüsler olmasına rağmen gereksiz antibiyotik kullanımı üst sıradadır. Grup A streptokok olarak bilinen Streptococcus pyogenes; akut tonsillofarenjitin en sık bakteriyel etkenidir. Çocuklarda tonsillofarenjit vakalarına neden olan Grup A streptokok oranı \%20 ile \%40 arasında değișmektedir. Grup A streptokok için tanıda altın standart boğaz kültürüdür. Ancak sonuçlanmasının 24-48 saat sürmesinden dolayı hızlı yöntemler geliștirilmiștir. Bu çalıșmada hızlı antijen tarama testi sonuçları ile kültür sonuçları karşılaștırılarak hızlı antijen testinin etkinliğinin değerlendirilmesi amaçlanmıştır.

Yöntem: Çalıșmada Şubat 2017-Ocak 2018 tarihleri arasında çocuk hastalıkları polikliniğine başvuran hastalardan tonsillofarenjit tanısıyla laboratuvarımıza gönderilen 297 boğaz sürüntüsü örneğinin sonucu retrospektif olarak değerlendirilmiștir. Alınan örneklerden biri ile boğaz kültürü için koyun kanlı agara ekimi yapılmıș, eș zamanlı diğer örnek ile hızlı antijen testi (TOYO, Türklab) çalıșılmıștır. Kültürde üreyen beta hemolitik

'Department of Medical Microbiology, Ahi Evran University, School of Medicine, Kirsehir

${ }^{2}$ Department of Pediatrics, Ahi Evran University, School of Medicine, Kirsehir, Turkey

İletişim / Corresponding Author : Fikriye MiLLETLI-SEZGIN

Ahi Evran Üniversitesi Tıp Fakültesi Bağbaşı Yerleşkesi 40100 Kırşehir - Türkiye

Tel : +905065871746 E-posta/E-mail : fikriye.sezgin@ahievran.edu.tr

Geliş Tarihi / Received : 12.04 .2018 Kabul Tarihi / Accepted : 04.01.2019

DOI ID : 10.5505/TurkHijyen.2019.54036

Milletli-Sezgin F, Ünlü E. Evaluation of rapid antigen test in child patients with group A streptococcal tonsillopharyngitis.

Turk Hij Den Biyol Derg, 2019; 76(3): 329-334 
other sample. For suspected growth of beta hemolytic colonies in the culture, bacitracin susceptibility and PYR tests were also carried out.

Results: A total of 297 patients were inspected with both culture test and rapid antigen test. The culture test was positive in $55(18.5 \%)$ of the samples, and the rapid antigen test in 51 (17.1\%). The rapid antigen test was determined to have a sensitivity of $83.6 \%$, specificity of $97.9 \%$, positive predictive value of $90 \%$, negative predictive value of $96.3 \%$, and accuracy of $95 \%$.

Conclusion: The utilization of the rapid antigen test for the diagnosis of Group A streptococcus tonsillopharyngitis will help restrain unnecessary use of antibiotics. The prevention of resistance development with proper use of antibiotics is of importance. Based on the results of our study, the specificity of the rapid test is high, but its sensitivity is lower. For this reason, confirming negative results from the rapid antigen test with the culture test is necessary with regard to undertreatment and complications.

Key Words: Group A streptococcus, rapid antigen test, throat culture, tonsillopharyngitis șüpheli kolonilerden basitrasin duyarlılığı ve PYR testi çalışılmıștır.

Bulgular: Toplam 297 hastada kültür ile hızlı antijen testi de çalıșılmıștır. Örneklerin 55 (\%18.5)'inde kültür pozitif, 51 (\%17.1)'inde hızlı antijen testi pozitif bulunmuștur. Hızlı antijen testinin duyarlılığı \%83,6, özgüllüğü \%97,9, pozitif kestirim değeri \%90, negatif kestirim değeri \%96,3, testin doğruluğu ise \%95 olarak saptanmıștır.

Sonuç: Grup A streptokok tonsillofarenjit tanısında hızlı antijen testinin kullanımı gereksiz antibiyotik kullanımının önüne geçilmesine katkı sağlayacaktır. Doğru antibiyotik kullanımı ile birlikte direnç gelișiminin önlenmesi de önemlidir. Çalıșmamızın sonucuna göre hızlı testin özgüllüğü yüksek, duyarlılığı daha düșüktür. Bu nedenle hızlı antijen testinde negatif bulunan sonuçların kültür ile doğrulanması eksik tedavi ve yan etki açısından gereklidir.

Anahtar Kelimeler: Grup A streptokok, hızlı antijen testi, boğaz kültürü, tonsillofarenjit

\section{INTRODUCTION}

Tonsillopharyngitis is most common causes of applying to a doctor among child patients (1). The causative microorganisms may be viral or bacterial. While viruses are the most common agents of tonsillopharyngitis in children younger than 3 years, the most predominant agent in children of ages 5-15 is Streptococcus pyogenes (Group A Streptococcus, GAS) with a rate of $15-20 \%$ (2). When a patient with acute tonsillopharyngitis is encountered, the most important decision is to decide whether the agent is viral or bacterial. An accurate diagnosis is important for the prevention of serious complications such as acute rheumatic fever and acute glomerulonephritis as well as restraining the unnecessary use of antibiotics. Therefore, the microbiological diagnosis needs to be made quickly and accurately.

The gold standard test used for GAS in microbiology laboratories is the throat culture test. However, obtaining a report with throat culture takes up to 48-72 hours. As a result, fast antigen tests were developed. The most widely used rapid antigen tests are the lateral flow immunoassay or methods based on rapid immunochromatography (3). This study aims to evaluate the effectiveness of the rapid antigen test (RAT) we utilize in our laboratory by comparing it with the culture test. 


\section{MATERIAL and METHOD}

Throat swab samples obtained from patients who had been diagnosed with tonsillopharyngitis at the pediatric diseases clinic of our hospital between the dates February 2017-January 2018 were included in the study. Two throat coton swab (Or-Bak, Turkey) samples were taken from the posterior pharynx and tonsils of the patients and sent to the microbiology laboratory. One of the samples was tested with the rapid antigen test (TOYO, Turklab) in accordance with the instructions of the manufacturer, while the other sample was inoculated to sheep blood agar and incubated for 48 hours at $37{ }^{\circ} \mathrm{C}$. The presence of beta hemolytic colonies in the plates was investigated at the 24th and 48th hours. Identification was ensured by performing the PYR kit (Bioanalyse, Turkey) and bacitracin (Bioanalyse, Turkey) susceptibility tests on the suspected colonies. The chi-square test was used as a statistical method.

\section{RESULTS}

Results from a total of 297 patients, of which 145 (44.5\%) were female and 152 (55.5\%) were male, were retrospectively evaluated in the study. The mean age was $5.6 \pm 2.9$ years. GAS growth in throat cultures was detected in 55 of the 297 throat swab samples included in the study. While positive RAT results were obtained with only 46 of these samples that produced positive culture growth results, in 5 samples, only RAT was found positive (Table 1). It was determined in our study that the rapid antigen test had a sensitivity of $83.6 \%$ and specificity of $97.9 \%$. The distribution of culture results based on sex demonstrated no significant differences $(p>0.05)$. Regarding the distribution of patients with positive culture results based on age; 11 patients were younger than the age of 5 , and 44 patients were in the 5-15 age range. The distribution of positive RAT and culture results based on seasons have been presented in Table 2 .

Table 1. The comparison of results from culture-rapid antigen tests

\begin{tabular}{lcccc}
\hline & \multicolumn{3}{c}{ Rapid antigen test } \\
\hline Group A Streptococcus Detection & Positive & Negative & Total \\
\hline \multirow{2}{*}{ Culture } & Positive & 46 & 9 & 55 \\
& Negative & 5 & 237 & 242 \\
\hline
\end{tabular}

Table 2. The evaluation of positive test results based on seasons

\begin{tabular}{ccc}
\hline & Positive culture test \% & Positive rapid test \% \\
\hline Winter & $17(30.9 \%)$ & $21(41.1 \%)$ \\
\hline Spring & $7(12.7 \%)$ & $3(15.7 \%)$ \\
\hline Summer & $3(5.5 \%)$ & $3.9 \%)$ \\
Fall & $28(50.9 \%)$ & $19(37.3 \%)$ \\
Total & $55(100 \%)$ & $51(100 \%)$
\end{tabular}




\section{DISCUSSION}

In children, rapid diagnosis and correct treatment of tonsillopharyngitis is important. Since GAS is the most common cause of bacterial tonsillopharyngitis where antibiotic treatment is necessary besides rare diseases such as diphtheria, tularemia, and Vincent angina, the main purpose is to identify cases of GAS tonsillopharyngitis. The rate of GAS was $18.5 \%$ in children according to the results of our study. When we reviewed the literature, the studies that were conducted in our country by Baris et al. in 2016 determined GAS positivity rates in children of ages 5-15 as $18.4 \%$, and Saygili et al. as 14.4 for the same age range in the same year $(3,4)$. In the study they carried out in 2014, Altun et al. determined this rate as $24.6 \%$ in the $0-18$ age range (5). Again in the $0-18$ age range, the GAS positivity rate was identified as $25 \%$ in a study done by Gozukucuk et al. (6). In a study by Kucuk et al. where they compared the age ranges of $0-6$ and 7-17, it was stated that the rate was as high as $35.9 \%$ in children of ages $7-17$, compared to $19.4 \%$ in the younger group (7). When studies done abroad were investigated, this rate was found to vary between $21-48 \%(8)$. When we consider the results of our study, we can say that they are in accordance with other studies.

In the recent years, rapid antigen tests of lateral flow immunoassay and new generation tests based on rapid immunochromatography methods have been widely used in the diagnosis of GAS $(8,9)$. Throat culture, on the other hand, is the gold standard testing method in the diagnosis of tonsillopharyngitis (10). However, since requiring 24-48 hours for the results can increase the unnecessary use of antibiotics, the utilization of tests that produce results in 5-10 minutes attract attention. In our study, the TOYO (Turklab) rapid antigen test was evaluated by taking the culture method as a reference and its sensitivity was determined as $83.6 \%$, specificity as $97.9 \%$, positive predictive value as $90 \%$, negative predictive value as $96.3 \%$, and accuracy as $95 \%$.
When studies done in our country were reviewed, varying rates were identified with different patient populations and kits (Table 3 ). Cohen et al. have reviewed studies that evaluated rapid antigen tests in children and reported the sensitivity of the tests to vary between $66-94 \%$ and their specificity to vary between $40-88 \%$ (8). 105 studies and approximately 116 different rapid antigen tests have been reviewed; the mean sensitivity of the rapid antigen tests was reported as $86 \%$, and their specificity as $95 \%$ (9). In a study published in 2010, a meta-analysis of 24 studies published between the years 2000-2009 was performed and rapid antigen tests were determined to have a sensitivity of $65.5-96.4 \%$, specificity of 68.7 $99.3 \%$, and positive and negative predictive values of 87.8-98\% and $59.4-97.4 \%$ respectively (11).

The sensitivities and specificities of rapid tests can be impacted by certain factors. The most predominant one is the quality of the collected sample. When we review the literature, studies can be found that investigate the effects of inoculum size. In a study conducted by Lasseter et al., test sensitivity was reported to increase with an increasing inoculum size (12). In a study by Baris et al., samples from a group that demonstrated intense growth which produced positive culture test results but negative rapid test results were analyzed again with a different brand, and 30 of the 31 samples tested positive with the other brand. They explained this outcome by emphasizing that the sensitivity of the test depended on the kit that was used, independently of the effects of inoculum (4). No differences between samples were detected in our study with regard to rates of growth in the cultures.

It is a known fact that antibiotics are used frequently and inappropriately in Turkey (13). Particularly in children, tonsillopharyngitis is the most common cause of consulting to clinics and the wide use of antibiotics draws attention. Physicians were administered surveys in a study done in our country, and it was determined that a sore throat was the third 
Table 3. The evaluation of the sensitivity and specificity outcomes of the kits compared to the culture test

\begin{tabular}{|c|c|c|c|}
\hline Kit brand & Sensitivity \% & Specifity \% & Publication \\
\hline $\begin{array}{l}\text { INTEX Strep A Test II (INTEX } \\
\text { Diagnostica, Muttenz, Schweiz) }\end{array}$ & 89.7 & 97.2 & $\begin{array}{c}\text { Camurdan et al.,(15) } \\
\text { 2008, Ankara }\end{array}$ \\
\hline Quikvue Strep A (Quidel San & 64.6 & 96.79 & $\begin{array}{l}\text { Gurol et al. (16) } \\
\text { 2010, İstanbul }\end{array}$ \\
\hline Diego USA) & 59.5 & 97.2 & $\begin{array}{l}\text { Kucuk et al. (7) } \\
\text { 2011, İstanbul }\end{array}$ \\
\hline $\begin{array}{l}\text { VIKIA Strep A } \\
\text { (Biomeriux, Fransa) }\end{array}$ & 66 & 99 & $\begin{array}{l}\text { Gozukucuk et al. (6) } \\
\text { 2011, İstanbul }\end{array}$ \\
\hline MK BIO Strep A & 100 & 97 & $\begin{array}{l}\text { Yardimci et al. (17) } \\
\text { 2012, İstanbul }\end{array}$ \\
\hline $\begin{array}{l}\text { Eco Test Strep A Rapid Test } \\
\text { (Weilkang, UK) }\end{array}$ & 68.1 & 92.2 & $\begin{array}{l}\text { Coban et al. (18) } \\
\text { 2013, Antalya }\end{array}$ \\
\hline $\begin{array}{l}\text { Abon Strep A Kit } \\
\text { (Hangzhou, China) }\end{array}$ & 73 & 96.8 & $\begin{array}{l}\text { Altun et al. (5) } \\
\text { 2015, Ankara }\end{array}$ \\
\hline $\begin{array}{lll}\text { Bionexia Strep A Plus } \\
\text { (Biomerieux, } & \text { Fransa) } & \end{array}$ & 84.1 & 100 & $\begin{array}{l}\text { Saygili et al. (3) } \\
\text { 2017, İstanbul }\end{array}$ \\
\hline $\begin{array}{l}\text { Mascia Brunelli Strep A Card } \\
\text { (Mascia Brunelli s.p.a, Italy) }\end{array}$ & 75.2 & 100 & $\begin{array}{l}\text { Baris et al. (4) } \\
\text { 2017, İstanbul }\end{array}$ \\
\hline
\end{tabular}

among the complaints that received a prescription of antibiotics (14). Therefore, the utilization of the rapid test on patients that present with the complaint of a sore throat is important. At our hospital, the results of RAT requested from child patients were reported within approximately half an hour. It is important that tonsillopharyngitis is diagnosed quickly and treated correctly in child patients. However, it is essential to consider culture test results and confirm the diagnosis in order to avert serious complications in children of ages 5-15. Laboratories must show care to prevent misdiagnoses and undertreatment by working with a kit that has a high sensitivity. 


\section{REFERENCES}

1. Tunger O. Akut Tonsillofarenjitler. CBU-SBED, 2015; $2(1): 2-7$

2. Koturoğlu G. Cocuklarda Üst Solunum Yolu Enfeksiyonları. J Pediatr Res, 2015; 2 (2): 62-5.

3. Sayğılı N, Bulut E, Deniz R, Dalgıç N, Aktaș E. Boğaz Sürüntü Örneklerinde A Grubu Beta-Hemolitik Streptokokların Belirlenmesinde Bionexia Strep A Plus Hızlı Antijen Testinin Kullanımı. Türk Mikrobiyol Cem Derg, 2017; 47 (3): 138-45.

4. Barıș A, Anlıaçık N, Bulut ME, Deniz R, Yücel E, Aktaș E. Evaluation of Mascia Brunelli rapid antigen test in the diagnosis of group A streptococcal pharyngitis. Mikrobiyol Bul, 2017; 51 (1): 73-8.

5. Altun HU, Meral T, Aribas ET. The specificity and sensitivity results of the rapid antigen test used in the diagnosis of group a beta hemolytic streptococcal tonsillopharyngitis. Acta Medica Mediterr, 2015; 31: 287-90.

6. Gözüküçük R, Göçmen I, Nas Y, Yılmazer F, Ünüvar E. Streptokoksik tonsillofarenjit tanısında strep-A hızlı testinin etkinliği. Çocuk Dergisi, 2011; 11: 157-9.

7. Küçük Ö, Biçer S, Giray T, Çöl D, Erdağ GC, Gürol Y, et al. Validity of rapid antigen detection testing in group a beta-hemolytic streptococcal tonsillopharyngitis. Indian J Pediatr, 2014; 81 (2): 138-42.

8. Cohen JF, Cohen R, Levy C, Thollot F, Benani M, Bidet $P$, et al. Selective testing strategies for diagnosing group A streptococcal infection in children with pharyngitis: a systematic review and prospective multicentre external validation study. CMAJ, 2015; 187 (1): 23-32.

9. Cohen JF, Bertille N, Cohen R, Chalumeau M. Rapid antigen detection test for group A streptococcus in children with pharyngitis. Cochrane Database Syst Rev 2016; 7:CD010502.

10. Van Brusselen D, Vlieghe E, Schelstraete $P$, De Meulder F, Vandeputte C, Garmyn K, et al. Streptococcal pharyngitis in children: to treat or not to treat? Eur J Pediatr, 2014; 173 (10): 1275-83.
11. Ruiz-Aragon J, Rodríguez RL, Molina JL, editors. Evaluation of rapid methods for detecting Streptococcus pyogenes. Systematic review and meta-analysis. An Pediatr (Barc), 2010; 72 (6): 391402.

12. Lasseter GM, McNulty CA, Richard Hobbs F, Mant $D$, Little $P$, investigators $P$. In vitro evaluation of five rapid antigen detection tests for group A betahaemolytic streptococcal sore throat infections. Fam Pract, 2009; 26(6): 437-44.

13. Karabay O. Birinci Basamakta Antibiyotik Kullanımında Türkiye'de Durum. ANKEM Derg, 2007; 21 (Ek 2): 252-6.

14. Çöplü N, İlhan MN, Ciliv EF, Șenlik ZB, Ertek M. Aile hekimleri ve uzmanlar arasında antimikrobiyallerin akılcı reçetelendirilmesi: tutum ve talepler. Turk Hij Den Biyol Derg, 2014; 71 (1): 19-26.

15. Camurdan AD, Camurdan OM, Ok I, Sahin F, Ithan $M N$, Beyazova U. Diagnostic value of rapid antigen detection test for streptococcal pharyngitis in a pediatric population. Int J Ped Otorhinolaryngol, 2008; 72 (8): 1203-6.

16. Gurol Y, Akan H, Izbirak G, Tekkanat ZT, Gunduz TS, Hayran $O$, et al. The sensitivity and the specifity of rapid antigen test in streptococcal upper respiratory tract infections. Int J Ped Otorhinolaryngol, 2010; 74 (6): 591-3.

17. Yardımcı AC, Fincancı M, Uysal BB, Erdenen F, Tekke NS, Yiğit Ö. Erișkinlerde Boğaz Ağrısı Nedeniyle Bașvuran Hastalarda Hızlı Strep Testi Sonuçlarının Değerlendirilmesi. Istanbul Med J, 2012; 13 (3): 112-4.

18. Coban B, Kaplan H, Topal B, Ülkü N. The sensitivity and the specifity of rapid antigen test in Group A streptococcal tonsillopharyngitis. J Pediatr Inf, 2013; 7: 143-6. 